\title{
Stress Response in Dairy Cows Related to Blood Glucose
}

\author{
P. MUDROŇ ${ }^{1}$, J. REHAGE ${ }^{2}$, H. P. SALLMANN ${ }^{2}$, M. HÖLTERSHINKEN ${ }^{2}$, H. SCHOLZ ${ }^{2}$ \\ 2nd Internal Clinic ${ }^{1}$, University of Veterinary Medicine, Košice, Slovak Republic \\ Clinic for Cattle ${ }^{2}$, Veterinary School Hannover, Germany
}

Received February 6, 2004

Accepted March 3, 2005

\begin{abstract}
Mudroň P., J. Rehage, H. P. Sallmann, M. Höltershinken, H. Scholz: Stress Response in Dairy Cows Related to Blood Glucose. Acta Vet. Brno 2005, 74: 37-42.

The aim of this study was to investigate whether different pre-surgical blood glucose concentrations have any effect on the course of cortisol and metabolic responses to surgical stress in dairy cows. Eighteen Holstein-Friesian dairy cows, admitted for treatment of left abomasal displacement (omentopexy), were used in the study. Abdominal surgery (the stressor) was performed in the standing position $16-24 \mathrm{~h}$ after admission and lasted approximately $60 \mathrm{~min}$. Blood samples were drawn from the jugular vein prior to surgery, immediately after and then 2, 5, 24 , and $72 \mathrm{~h}$ after surgery. In order to test the effect of the different blood glucose levels on stress responses the experimental animals were allocated to two groups: 1) six hypoglycaemic cows (glucose $<2.4 \mathrm{mmol} / \mathrm{l}$ ); 2) twelve normoglycaemic cows. Surgery increased blood glucose in both groups $(p<0.001)$, however, the glucose rise was less distinct in the hypoglycaemic cows. The surgical stress resulted in a significant increase in plasma cortisol concentrations in both groups $(p<0.001)$, however there was no difference in cortisol responses between the groups. Similarly, surgery enhanced the blood concentrations of free fatty acids (FFA) and L (+)-lactate in both groups $(p<0.001)$. In contrast, $\beta$-hydroxybutyrate concentrations slightly declined after surgery. On the basis of this study there appears not to be any effect of different plasma glucose on the cortisol and metabolite responses in stressed dairy cows. Therefore, it can be concluded that mechanisms regulating peripheral cortisol concentrations, and thus the animal stress response, are more dependent on the intensity of the stressful stimulus than on the energetic status of animal.
\end{abstract}

Cattle, glucose, cortisol, omentopexy, stress

Adaptation reactions or stress reactions represent a modification of ongoing physiological mechanisms that allow an animal to respond to stress stimuli with minimum alteration in homeostasis. Although stress reactions are organized to protect the homeostatic state of animals, they contain elements that may either enhance or diminish susceptibility to the disease process; in many instances, however, stress reactions themselves may induce pathologic change (Breazile 1988). Stress responses may include changes in feeding behaviour, hypertension, reproductive dysfunction, inefficient feed conversion, gastric and intestinal ulcers, electrolyte imbalance and immune deficiency (Alams and Dobson 1986).

The major stress alterations involve enhanced secretion of glucocorticoids and increased sympathetic nervous system activity. Synchronised control of hypothalamic releasing hormones of ACTH and of catecholamines results in biochemical and physiologic manifestations of stress (Nockels 1990). It was demonstrated that a number of manipulations including transport (Locatelli et al. 1989), feed deprivation (Fürll et al. 1993), therapeutic manipulation (Nakao et al. 1994), and surgery (Fisher et al. 2001; Sylvester et al. 1998), increased secretion of cortisol from the adrenal cortex in cattle. One of the most important benefits of increased glucocorticoid secretion in stress concerns the maintenance of flight response with essential metabolites by diverting glucose metabolism from muscle to the brain and other tissues. However, there are no reports of possible links

Address for correspondence:

Prof. MVDr. Pavol Mudroň, PhD.

University of Veterinary Medicine

Komenského 73, 04181 Košice

Slovak Republic
Phone: +421 556338071

Fax: +421556323666

E-mail:pmudron@hotmail.com

http://www.vfu.cz/acta-vet/actavet.htm 


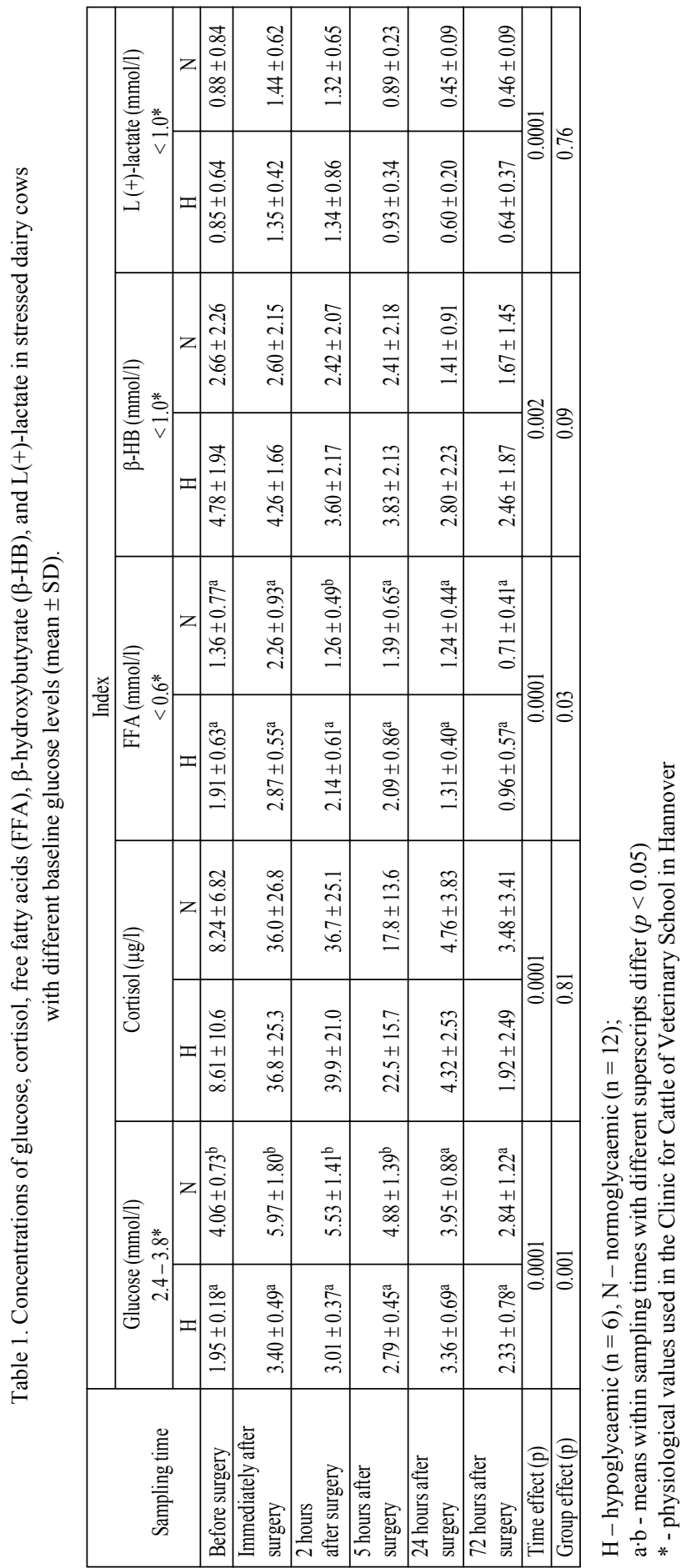


between the intensity of stress responses and blood glucose levels in cattle. The stressed animals can be frequently in a negative energy balance, characterised by hypoglycaemia. Such hypoglycaemic conditions can commonly occur in dairy cows in the periparturient period (Karsai and Gaal 1987; Nikolic et al. 2003), or in animals undergoing surgical treatment, including omentopexy or ceasarian section, since their pre-treatment feed intake is usually reduced and they are frequently suffering from varying degrees of ketosis (Stö b er and Scholz 1991).

Therefore, it was decided to design an experiment to investigate whether different presurgical blood glucose levels are related to the course of cortisol and metabolic responses to surgical stress in dairy cows.

\section{Materials and Methods}

Eighteen Holstein-Friesian dairy cows, mean age of four years, admitted for treatment for left abomasal displacement, were used in the study. Abdominal surgery (omentopexy) was performed in the standing position (Dirksen 1967) within $24 \mathrm{~h}$ of admission. Isocain ( $2 \%$ procain-hydrochloride, ASID GmbH, Germany) was used as local anaesthesia. The mean duration of preparation for surgery lasted 30-40 min, and the surgery approximately 60 minutes.

Blood samples were drawn by venipuncture from the jugular vein prior to surgery, immediately after and then $2,5,24$, and $72 \mathrm{~h}$ after surgery. Serum concentrations of glucose, free fatty acids, and $\beta$-hydroxybutyrate were measured using an automatic analysing system (COBAS MIRA ${ }^{\circledR}$, Hoffman La Roche, D-79630 GrenzachWyhlan). The serum was obtained within 30 minutes of blood collection (the blood was incubated for 15 min in plastic test tubes with small round plastic particles at $38{ }^{\circ} \mathrm{C}$ and then centrifuged) and then stored frozen at $-80^{\circ} \mathrm{C}$ until analysed. In the EDTA plasma the cortisol and L (+)-lactate levels were assayed. The plasma cortisol levels were determined by a radioimmunoassay kit (Coat - A - Count [125I]; Diagnostic Products Cooperation, L.A., USA). Plasma L (+)-lactate levels were determined fluorometrically after reaction with L (+)-lactate dehydrogenase. In order to test the effect of the different blood glucose levels on stress responses, the experimental animals were allocated to two groups: 1) six hypoglycaemic dairy cows (glucose $<2.4 \mathrm{mmol} / \mathrm{l}$ ); 2) twelve normoglycaemic dairy cows (Scholz 1990).

Statistical analysis was carried out by a two-factorial analysis of variance (one repeated factor:time, one grouping factor: treatment) using the GLM procedure of SAS for repeated measures. In cases where ANOVA model revealed a significant group effect, Student's $t$-test was performed in order to check group differences at each sampling.

\section{Results}

The blood glucose levels were affected by surgical stress in both groups $(p<0.001)$. The lower glucose levels in the hypoglycaemic animals appeared within five hours after surgery (Table 1). No significant differences in blood glucose levels were recognized between the groups later, at the last two sampling times ( 24 and $72 \mathrm{~h}$, respectively).

The surgical stress resulted in significant changes in plasma cortisol concentrations in both groups $(p<0.001)$. The highest cortisol levels were reached within two hours after surgery and were approx. four times higher than those found prior to stress. A return to the levels below the initial ones was recognized 24 hours after surgery. The ANOVA revealed no significant effect of plasma glucose levels on cortisol response due to surgical stress (Table 1).

The surgical stress had enhancing effects on the blood concentrations of free fatty acids and $\mathrm{L}(+)$-lactate in both groups $(p<0.001)$. The highest concentrations of these were seen immediately after surgery. Then they decreased, and three days after surgery they were below the pre-surgical data (Table 1). A significant difference in concentrations of FFA between the groups was seen two hours after surgery $(p<0.05)$, which corresponded with intergroup differences in glucose levels. In contrast to glucose with FFA and lactate, the $\beta$-hydroxybutyrate concentrations slightly declined after surgery. The minimum serum $\beta$ $\mathrm{HB}$ in the hypoglycaemic group occurred 24 hours after surgery and in the normoglycaemic group at hour 72 (Table 1). 


\section{Discussion}

Hypoglycaemia in six dairy cows, found prior to surgery, was associated with elevated levels of free fatty acids, and thus indicated a more severe negative energy balance in this group compared with normoglycaemic animals. It was demonstrated that dairy cows with left displacement of the abomasum frequently suffer from peripheral fat mobilisation due to energy deficit (Rehage 1996; Mudroň et al. 1997). Surgical stress resulted in elevation of blood glucose in both hypoglycaemic and normoglycaemic groups, although in the hypoglycaemic group lower glucose concentrations persisted five hours after surgery. Similarly to our results, a short-term rise of glucose, lasting approximately six hours, was seen in cattle after transportation (Hartmann et al. 1973). Hyperglycaemia is reported to occur in response to some but not all stressors, but invariably in response to severe stressors, eg. physical trauma (Moberg 1985). However, blood glucose is not a very reliable indicator of the stress intensity in animals as its levels can be affected by various factors ( $\mathrm{Scholz}$ 1990). The 24-hour-increase in glucose concentrations in both groups recognized after surgery in our study can be explained as a response to catecholamine and cortisol rise. The existing glucose is an exclusive energy source for the red blood cells and portions of the central nervous system during periods of stress (Nockels 1990).

Mean plasma cortisol levels of $1-10 \mu \mathrm{g} / 1$ were found in dairy cows during the first month after calving (Madej 1992). Hopster et al. (1999) concluded that $69.4 \%$ of 307 baseline cortisol samples had concentrations below $3 \mu \mathrm{g} / \mathrm{l}$, whereas $13.7 \%$ of the samples contained $6 \mu \mathrm{g} / \mathrm{l}$ of cortisol or more. Similar cortisol concentrations have also been defined by others as baseline values (Naka o et al. 1994; Bruckmaier et al. 1996; Hopster et al. 2002). The mean cortisol values prior to surgery, and at 24 and $72 \mathrm{~h}$ after surgery in both hypoglycaemic and normoglycaemic cows can, therefore, safely be considered to be in the normal range of baseline concentrations. The relatively higher values that were found before surgery may have been due to circadian and ultradian rhythms which were previously investigated under strict control of experimental conditions in lactating dairy cows (Lefcourt et al. 1993). Moreover, the stressful effect of the displacement of the abomasum should also be considered as a possible factor of the higher pre-surgical cortisol levels. Although distinct individual variations of cortisol concentrations were seen in the study, no significant differences in cortisol responses to surgery could be found between the experimental groups. When intergroup differences in blood glucose are considered, the results of this study indicate that mechanisms regulating peripheral glucocorticoid concentrations depend less on the energetic status of animals, than on the intensity of stressful stimulus. The significant effect of surgery on the increase in plasma cortisol levels was similar to that previously reported in cattle after laparotomy (Janowski et al. 1983). The pattern of cortisol concentrations seen after surgery in this study was similar to the pattern seen in 5-6-monthold cattle after amputation dehorning (Sylvester et al. 1998).

The surgery resulted in transient elevation of free fatty acids from the baseline values. In addition, two hours after surgery, when the highest plasma cortisol concentrations were measured, significantly higher levels of free fatty acids in the serum could be recognized in the hypoglycaemic groups. This could be explained as a reaction to the higher energy needs of cows suffering from a more severe energy deficiency. The lipolysis of fat tissue was obviously a response to both high cortisol levels and low glucose entry into adipocytes. In addition, the lipomobilisation seen in this study was probably also due to the effects of catecholamines, since an increase in both glucose and lactate in dairy cows could be recognised after surgery. Catecholamines exercise a strong stimulating effect on glycolysis and precipitate tissue hypoxia (Mitchell et al. 1988); the result of which can be tissue metabolic acidosis ( $\mathrm{Nagy}$ et al. 1994). The high plasma concentrations of $\beta$-hydroxybutyrate during the whole experiment reflected the energy deficiency in dairy 
cows in both groups (Gaal et al. 1993). In accordance with the strong antiketogenic effects of glucocorticoids (Fürll et al. 1993) a slight decline in $\beta$-hydroxybutyrate levels was recognised within two hours after surgery when cortisol was elevated. Due to health improvement and increased feed intake by animals within three days after surgery, such dynamics continued until the trial ended.

On the basis of this study it appears that different blood plasma glucose levels do not have any effect on the cortisol and metabolite response in stressed dairy cows. Therefore, it can be concluded that mechanisms regulating peripheral cortisol concentrations, and thus the animal's stress response, are more dependent on the intensity of the stressful stimulus than on the energetic status of animal.

\section{Stresová reakcia dojníc s rôznou hladinou glukózy v krvi}

Cielom našej štúdie bolo zistit, či odlišné predoperačné hladiny glukózy v krvi môžu ovplyvnit koncentráciu kortizolu a metabolické parametre u dojníc vystavených chirurgickej zátaži. Do experimentu bolo zaradených 18 dojníc, holštejnsko-frízskeho plemena, ktoré boli prijaté na kliniku za účelom terapie lavostranného premiestnenia slezu (omentopexia). Chirurgický zákrok (stresor) bol vykonaný na stojacich zvieratách približne 16-24 hodín po prijatí na kliniku. Celá operácia trvala v priemere 60 minút a bola robená v lokálnej anestéze. Vzorky krvi boli odoberané $\mathrm{z} v$. jugularis pred operáciou, bezprostredne po nej, a potom 2, 5, 24 a 72 hodín po operácii. Za účelom posúdenia účinku rôznych hladín glukózy na stresovú reakciu boli pokusné dojnice rozdelené do dvoch skupín: 1) 6 hypoglykemických dojníc (glukóza $<2,4 \mathrm{mmol} / \mathrm{l} ; 2) 12$ normoglykemických dojníc. Operácia mala za následok zvýšenie glukózy v krvi u obidvoch skupín $(p<0,001)$, avšak jej vzostup bol menej výrazný u hypoglykemických zvierat. Chirurgický stres vyvolal signifikantný nárast plazmatického kortizolu u obidvoch skupín $(p<0,001)$, bez rozdielu $\mathrm{v}$ jeho intenzite medzi skupinami. V obidvoch skupinách stúpli po operácii aj koncentrácie volných mastných kyselín a L (+)-laktátu. Naopak, pri hladinách kyseliny $\beta$ hydroxymaslovej sme zaznamenali mierny pooperačný pokles. Na základe dosiahnutých výsledkov je možné konštatovat, že stresová a metabolická reakcia na operačný stresor nebola $\mathrm{v}$ našom experimente ovplyvnená predoperačnou hladinou glukózy. Dá sa predpokladat', že mechanizmy regulujúce periférnu hladinu kortizolu sú viac závislé na intenzite stresujúceho stimulu ako na energetickom stave zvierat.

\section{References}

ALAMS, MGS, DOBSON, H 1986: Effect of various veterinary procedures on plasma concentrations of cortisol, luteinizing hormone and prostaglandine F2 $\alpha$ metabolite in the cow. Vet Rec 118: 7-10

BREAZILE, JE 1988: The physiology of stress and its relationship to mechanisms of disease and therapeutics. Veter Clin N Amer Fd Anim Pract 4: 441-480

BRUCKMAIER, RM, PFEILSTICKER, HU, BLUM, JW 1996: Milk yield, oxytocin and $\beta$-endorphin gradually normalize during repeated milking in unfamiliar surroundings. J Dairy Res 63: 191-200

DIRKSEN, G 1967: Gegenwärtiger Stand der Diagnostik, Therapie und Prophylaxe der Dislocatio abomasi sinistra des Rindes. Dtsch Tierärztl Wschr 74: 625-633

FISHER, AD, KNIGHT, TW, COSGROVE, GP, DEATH, AF, ANDERSON, CB, DUGANZICH, DM, MATTHEWS, LR 2001: Effects of surgical or banding castration on stress responses and behaviour of bulls. Aust Vet J 79: 279-84

FÜRLL, M, KIRBACH, H, KNOBLOCH, B 1993: Glukokortikosteroideinfluss auf die fastenstimulierte Lipolyse und die Leberfunktion bei Kühen. Tierärztl Prax 21: 399-403

GAAL, T, MEZES, M, MISKUCZA, O, RIBICZEY-SZABO, P 1993: Effect of fasting on blood lipid peroxidation parameters of sheep. Res Vet Sci 55: 104-107

HARTMANN, H, MEYER, H, STEINBACH, G, FINGER, B 1973: Zu Reaktion des Kälberorganismus auf Transportbelastungen. Mh Vet-Med 28: 647-651

HOPSTER, H, BRUCKMAIER, RM, VAN DER WERF, JTN, KORTE, SM, MACUHOVA, J, KORTE-BOUWS, G, VAN REENEN, CG 2002: Stress responses during milking; comparing conventional and automatic milking in primiparous dairy cows. J Dairy Sci 83: 3206-3216 
HOPSTER, H, VAN DER WERF, JTN, ERKENS, JHF, BLOKHUIS, HJ 1999: Effects of repeated jugular puncture on plasma cortisol concentrations in loose-housed dairy cows. J Anim Sci 77: 708-714

JANOWSKI, T, GRUNERT, E, ZAREMBA, W 1983: Untersuchungen über den Steroidhormonspiegel bei hochtragenden, im Abstand von 1 bis 2 Tagen zweimal laparomierten Kühen der Rasse ,Deutsche Schwarzbunte“. Zuchthygiene (BERL.) 18: 193-202

KARSAI, F, GAAL, T 1987: Changes of certain parameters of fat metabolism in dairy cows during the peripartum period. Dtsch Tierarztl Wochenschr 94: 264-268

LEFCOURT, AM, BITMAN, J, KAHL, S, WOOD, DL 1993: Circadian and ultradian rhythms of peripheral cortisol concentrations in lactating dairy cows. J Dairy Sci 76: 2607-2612

LOCATELLI, A, SARTORELLI, P, AGNES, F, BONDIOLOTTI, GP, PICOTTI, GB 1989: Adrenal response in the calf to repeated simulated transport. Br Vet J 145: 517-522

MADEJ, A, OYEDIPE, EO, EDQVIST, LE, KINDAHL, H 1992: Hormonal interrelationships in postpartum suckled dairy cows. Acta Vet Scand 33: 261-271

MITCHELL, G, HATTINGH, J, GANHAO, M 1988: Stress in cattle assessed after handling, after transport and after slaughter. Vet Rec 123: 201-205

MOBERG, GP 1985: Animal stress. American Physiological Society, Bethesda, 324.

MUDRON, P, REHAGE, J, SALLMANN, HP, MERTENS, M, SCHOLZ, H, KOVAC, G 1997: Plasma and liver $\alpha$-tokoferol in dairy cows with left abomasal displacement and fatty liver. J Vet Me. A 44: 91-97

NAGY, O, SEDOVIC, M, SLANINA, L 1994: Central and peripheral arterial and venous blood in cattle with respect to acid-base balance evaluations (In Slovak). Vet Med-Czech 39: 1-9

NAKAO, T, SATO, T, MORIYOSHI, M, KAWATA, K 1994: Plasma cortisol response in dairy cows to vaginoscopy, genital palpation per rectum and artificial insemination. J Vet Med A 41: 16-21

NIKOLIC, JA, KULCSAR, M, KATAI, L, NEDIC, O, JANOSI, S, HUSZENICZA, G 2003: Periparturient endocrine and metabolic changes in healthy cows and in cows affected by mastitis. J Vet Med A 50: 57-61

NOCKELS, CF 1990: Mineral alterations associated with stress, trauma, and infection and the effect on immunity. Cont Educ Pract Vet 12: 1133-1139

REHAGE, J 1996: Untersuchungen zur Leberfunktion von Milchkühen mit Leberverfettung am Modell von Patienten mit linksseitiger Labmagenverlagerung. Habilitationsschrift, Hannover

SCHOLZ, H 1990: Stoffwechselkontrolle in der Milchkuhherde an Hand von Blut- und Milchparametern. Prakt Tierarzt Coll Vet 21: 32-35

STÖBER, M, SCHOLZ, H 1991: Therapie des Lipomobilisationssyndroms der Milchkuh. Mh Vet-Med 46: 563-566

SYLVESTER, SP, STAFFORD, KJ, MELLOR, DJ, BRUCE, RA, WARD, RN 1998: Acute cortisol responses of calves to four methods of dehorning by amputation. Aust Vet J 76: 123-126 